Jurnal Justitia Vol. 1 No. 01 Agustus 2018

\title{
PERTANGGUNGJAWABAN KORPORASI TERHADAP TINDAK PIDANA LINGKUNGAN HIDUP MENURUT UNDANG- UNDANG NOMOR 23 TAHUN 1997
}

\author{
Oleh: Ridwan
}

Rangkuti ${ }^{1}$

\begin{abstract}
Abstrak
Penelitian ini untuk mengetahui pengaturan pertanggungjawaban korporasi, yang menjadi indikator sehingga pimpinan korporasi dapat diminta pertanggungjawaban serta bentuk pertanggungjawaban korporasi secara pidana dan perdata terhadap tindak pidana pencemaran dan atau perusakan lingkungan hidup menurut Undang-Undang Nomor 23 tahun 1997. Metode penelitian yang digunkan adalah metode normatif dan empiris dengan sumber informasi dari bahan primair dan skunder, serta alat pengumpulan data melalui wawancara dan studi dokumen berupa Putusan Pengadilan Negeri Padangsidimpuan. Berdasarkan hasil penelitian diperoleh bahwa pengaturan pertanggungjawaban korporasi, indikator pimpinan korporasi yang dapat diminta pertanggungjawaban serta bentuk pertanggungjawaban yang dapat dibebankan kepada pimpinan korporasi telah secara memadai diatur dalam Undang-Undang Nomor 23 tahun 1997, yaitu pimpinan korporasi yang melaksanakan kegiatan usahanya telah menimbulkan pencemaran dan atau perusakan lingkungan hidup dapat dihukum pidana ditambah dengan denda ganti rugi menurut hukum perdata.
\end{abstract}

Kata Kunci: Pertanggung jawaban, korporasi, lingkungan hidup

\section{PENDAHULUAN}

Sebagai karunia Tuham Yang Maha Esa, Sumber Daya Alam Indonesia harus dapat dimanfaatkan sebesar-besarnya bagi kemakmuran dan kesejahteraan bangsa Indonesia. Untuk itu perlu dan sangat penting terciptanya hubungan yang seimbang dan setara antara pelestarian sumber daya alam dengan pemanfaatan sumber daya alam tersebut sehingga tidak terjadi pencemaran atau perusakan lingkungan.h Sehubungan dengan hal tersebut guna menjaga hubungan yang seimbang dan setara tersebut Pemerintah bersama DPR telah mengesahkan Undang-

1 Ridwan Rangkuti, SH.,MH., adalah Dosen Fakultas Hukum Universitas Muhammadiyah Tapanuli Selatan Padangsidimpuan 
Jurnal Justitia Vol. 1 No. 01 Agustus 2018

Undang Nomor 4 Tahun 1982 tentang Ketentuan-Ketentuan Pokok Pengelolaan Lingkungan HIdup, yang kemudian di sempurnakan dengan Undang-Undang Nomor 23 Tahun 1997 tentang Pengelolaan Lingkungan Hidup.

Perkembangan global yang berdampak langsung kepada meningkatnya pembangunan di Indonesia, maka timbul suatu problem tentang pembangunan yang dibutuhkan masyarakat disisi lain upaya mempertahankan kelestarian hidup. Laju pertumbuhan penduduk Indonesia yang tidak sebanding dengan pertumbuhan ekonomi, berdampak langsung kepada mata pencaharian masyarakat yang cendrung vervyat nekat dan prustasi, salah satu dampaknya adalah banya knya warga masyarakat yang menggantungkan hidupnya dari sector kehutanan atau eksploitasi hasil hutan seperti kayu, rotan dan lain-lain. Pembukaan lahan pertanian yang baru.

Pada bagian lain pembangunan sektor perkebunan di Indonesia telah merubah sebagian wajah permukaan bumi Indonesia dari hutan yang menghijau menjadi hamparan kelapa sawit dan karet, perusahaanperusahaan besar seakan berlomba menanamkan investasinya di Indonesia pada sektor perkebunan, karena tanah Indonesia cukup subur dijadikan lahan perkebunan besar, sehingga dalam pembukaan lahan perkebunan tersebut tidak jarang terjadi eksplotasi hutan secara besarbesaran, pembakaran hasi tebangan (land crusing) yang berdampak langsung terhadap lingkungan hidup, tercemarnya udara karema asap pembakaran kayu hasil hutan tebangan, terganggunya suaka marga satwa dan paling rawan terjadinya banjir dan tanah longsor.

Hal inilah yang menjadi dasar pemikiran penulis dan melatarbelakangi Penulis memilih topik pertanggungjawaban hukum korporasi dalam penegakan hukum lingkungan. 
Sedangkan permasalahan dalam penelitian ini adalah pertama, bagaimanakah pengaturan pertanggungjawaban korporasi terhadap tindak pidana pencemaran dan/atau perusakan lingkungan hidup menurut UU Nomor 23 Tahun 1997 ? Kedua, apakah yang menjadi indikator sehingga pimpinan korporasi dapat diminta pertanggungjawaban hukum terhadap tindak pidana pencemaran dan/atau perusakan lingkungan hidup? Ketiga, bagaimanakan bentuk pertanggung jawaban/hukum yang dapat dibebankan kepada korporasi terhadap tindak pidana pencemaran dan /atau perusakan lingkuangan hidup yang dilakukannya?

\section{METODE PENELITIAN}

Penelitian ini termasuk penelitian hukum normatif-empiris. "Penelitian hukum normatif-empiris, mengkaji pelaksanaan atau implementasi ketentuan hukum positif (perundang-undangan) secara faktual pada setiap peristiswa hukum tertentu yang terjadi dalam masyarakat guna mencapai tujuan yang telah ditentukan". Dalam hal ini yang dikaji adalah pelaksanaan atau implementasi dari ketentuan UU No.

23 tahun 1997 tentang Lingkungan Hidup.

Dalam penelitian ini, kajian tahap pertama adalah kajian bentuk pertanggung jawaban perusakan/korporasi dalam tindak pidana Lingkungan Hidup. Sedangkan tahap kedua adalah kajian terhadap implementasi pertanggung jawaban korporasi tersebut yaitu penerapannya pada Pengadilan Negeri Padangsidimpuan.

Lokasi penelitian adalah di Kabupaten Tapanuli Selatan sebagai lokasi penelitian karena di daerah ini terdapat kasus lingkungan hidup yang dilakukan perusahaan pemegang izin perkebunan, sehingga patut untuk diteliti apakah perusahaan pemegang izin perkebunan tersebut dapat dipertanggungjawabkan atas kerusakan lingkungan hidup yang diperbuatnya. 
Populasi dalam penelitian ini adalah orang yang pernah dijatuhi hukuman pidana oleh Pengadilan Negeri Padangsidimpuan karena melakukan tindak pidana Lingkungan Hidup. Sedangkan yang menjadi sampel adalah perorangan/warga masyarakat dan instansi pemerintah.

Alat pengumpulan data dalam penelitian ini antara lain adalah studi dokumen atau bahan pustaka. Dalam penelitian ini pengumpulan data atau bahan hukum primair dilakukan melalui studi keperpustakaan, dan dokumen yang dapat berupa putusan pengadilan, kemudian dikaji pula bahan hukum skunder berupa karya para ahli hukum, dan untuk melengkapi bahan-bahan hukum ditunjang dengan bahan hukum tertier seperti kamus dan ensiklopedi. Kemudian wawancara dilakukan terhadap individu atau perorangan yang pernah menjadi terdakwa atau terpidana dalam kasus tindak pidana pencemaran pengrusakan lingkungan hidup. Wawancara dilakukan secara terarah sesuai dengan topik penelitian, untuk itu dalam pelaksanaan wawancara dibuat pedoman wawancara, sehingga hasil wawancara relevan dengan permasalahan yang akan diteliti. Wawancara juga dilakukan terhadap aparat penegak hukum yang pernah menangani kasus tindak pidana lingkungan hidup yang dilakukan korporasi, hal ini dilakukan untuk melengkapi bahan data yang diambil secara skumder. Dalam pengumpulan data juga dilakukan dengan cara mengajukan pertanyaan tertulis dalam bentuk tertutup dan terbuka yang ditujukan kepada aparat penegak hukum dan pimpinan perusahaan yang bergerak dalam bidang perkebunan yang pernah melakukan pencemaran lingkungan hidup.

Data yang diperoleh dari bahan hukum primeir dan skunder berupa peraturan perundang-undangan, pendapat dari pakar hukum lingkungan, serta putusan pengadilan, demikian juga dengan data primer yang diperoleh dari nara sumber atau responden disusun secara kualitatif untuk mendapatkan gambaran mengenai ketentuan pertanggung jawaban 
korporasi dalam tindak pidana lingkungan hidup, serta bentuk-bentuk pertanggung jawaban yang dapat dibebankan kepada korporasi yang terbukti melakukan tindak pidana pencemaran atau pengerusakan lingkungan hidup.

Dalam menarik kesimpulan terhadap analisis data yang diperoleh dalam penelitian ini, digunakan gabungan dari metode berfikir dedukatif dan silogisme.

\section{PEMBAHASAN}

\section{A. Pertanggung Jawaban Secara Hukum Perdata}

Menurut hukum perdata setiap perbuatan yang bertentangan dengan hukum harus dipertanggung jawabkan atas sejumlah kerugian yang diderita pihak lain, suatu perbuatan menurut perkembangan ilmu hukum, terutama melalui turisprudensi, tidak saja mencakup perbuatan yang bertentangan dengan hukurn dan hak dari pihak lain², tetapi juga setiap perbuatan yang bertentangan dengan kepatutan dalam pergaulan masyarakat, baik dalam hubungannnya dengan pribadi maupun harta benda orang lain ${ }^{3}$. Suatu proses tanggung jawab membayar ganti rugi lazimnya dikaitkan dengan hal tertentu yang menjadi penyebab timbulnya kerugian, yaitu terdapatnya unsur kesalahan pada pihak pelaku perbuatan.

Dalam sistem hukum perdata kita (termasuk yurisprudensi) banyak diwarnai oleh sistim Common Law. Menurut sistem ini suatu perbuatan yang bertentangan dengan hukum yang menimbulkan kerugian pada pihak lain, akan mewajibkan si pembuat kesalahan bertanggung jawab membayar ganti rugi atas akibat yang

\footnotetext{
2 R. Subekti, Pokok-Pokok Hukum Perdata, Jakarta, 1975

${ }^{3}$ Komar Kantaatmadja, Ganti Rugi Internasional Pencemaran Minyak laut, Jakarta, 1981.
} 
ditimbulkannya. Dengan jelas sistem yang demikian tercennin dalam Kitab Undang-Undang Hukum Perdata Pasal 1365. ${ }^{4}$

Setiap perbuatan melanggar hukum yang membawa kerugian kepada orang lain mewajibkan omg yang karena kesalahannya menimbulkan kerugian itu harus mengganti kerugian tersebut.

Pasal tersebut merupakan formula yang membuat prinsip tanggung jawab secar kesalahan (fouft). Asas pertanggung jawaban secara kesalahan didasarkan pada adabium bahwa tidak ada pertanggung jawaban apabila tidak terdapat unsur kesalahan (noliability without foult).

Adapun unsur-unsur perbuatan melawan hukum (onrechts matigedaad) menurut Pasal 1365 KUH Perdata adalah 5 :

1. Perbuatan itu harus bersifat melawan hukum

2. Terdapatnya kesalahan pada pelaku

3. Timbul kerugian

4. Terdapat hubungan kausalitas antara perbuatan dengan kerugian.

Sesuai dengan unsur-unsur tersebut, seseorang baru bisa dinyatakan bertanggung jawab kalau ke empat unsur di atas dipenuhi, namun melihat unsur-unsur ini terutama unsur kedua yakni unsur kesalahan (Foult, schuld atau Mens Area) sering menjadi beban bagi pihak yang diwajibkan membuktikannya.

Dalam sistim hukum perdata pembuktian dibebankan kepada pihak yang menderita (yang dirugikan), pembuktian kesalahan darisuatu perbuatan menjadi semakain pelik dan akibatnya, tidak jarang membuat korban sudah jatuh ditimpa tangga dengan pengertian bahwa korban untuk dapat membuktikan hal itu sangat sulit karena ia tidak mempunyai pengetahuan yang mendalam tentang hal itu, sehingga banyak tanggung jawab perdata atau tanggung gugat perdata tidak diatur secara khusus dalam Peraturan Pemerintah Nomor 28 Tahun 1985, namun tanggung

${ }^{4}$ R. Subekti, 1989,Undang-Undang Hukum Perdata, hal. 310.

${ }^{5}$ R. Subekti, Op.Cit. 
jawab perdata kini telah diatur dalam Pasal 80 Undang-Undang No. 41 Tahun 1999 tentang Kehutanan, Pasal 1365 KUH Perdata dan pasal 20 Undang-Undang No. 4 Tahun 1982, tentang ketentuan pokok lingkungan hidup jo pasal 34 sampai dengan pasal 35 Undang-Undang No. 23 Tahun 1997 tentang Pengelolaan Lingkungan Hidup.

Pada pasal 80 ayat I Undang-Undang No. 41 Tahun 19996: "setiap perbuatan melanggar hukum yang diatur dalam Undang-Undang ini dengan tidak mengurangi sanksi pidana sebagaimana diatur dalam pasal 78, mewajibkan kepada penanggung jawab perbuatan untuk membayar ganti rugi sesuai dengan tingkat kerusakan atau akibat yang ditimbulkan kepada negara, untuk biaya rehabilitasi pemulihan kondisi hutan, atau tindakan lain yang diperlukan.

Lebih dipertegas lagi bahwa siapa saja yang dapat dimintai pertanggung jawaban dan biaya apa saja yang dikeluarkan oleh penanggung jawab terhadap kerusakan hutan.

Dalam pasal 1365 KUH Perdata7, yaitu perbuatan yang bertentangan dengan hak orang lain yang timbul karena undang-undang (tidak ada hukum diluar undang-undang), namun dalam perkembangan pengertian perbuatan melawan hukum menganut arti luas.

Kewajiban hukum hanya kewajiban yang dirumuskan dalam aturan Undang-Undang (dalam arti materilyaitu aturan yang mengikat secara umum berasal dari kekuasaan yang memiliki wewenang).

1. Bertentangan dengan kesusilaan, artinya bahwa perbuatan yang dilakukan oleh seseorang itu bertentangan dengan sopan santun yang tidak tertulis yang tumbuh dan berkembang dalarn masyarakat.

2. Bertentangan dengan kecermatan yang harus diindahkan dalam masyarakat apabila diperhatikan persyaratan tersebut tampaklah bahwa ketentuan pasal 1365 KitabUndang-Undang

${ }^{6}$ Undang-Undang No. 41 tahun 1999 tentang Kehutanan.

${ }^{7}$ R. Subekti, Op.Cit., hal. 310. 
Hukum Perdata $(\mathrm{KUHP})^{8}$ dapat diterapkan kepada para tergugat yang telah melakukan perbuatan melawan hukum.

Untuk dapat menuntut ganti rugi kepada tergugat, pihak tergugat harus dapat membuktikan bahwa perbuatan melawan hukum itu dilakukan tergugat pihak penggugat harus dapat menaksirkan jumlah kerugian yang di deritanya, baik kerugian materil maupun immateril, disamping itu pihak penggugat juga harus membuktikan bahwa yang melakukan perbuatan tersebut adalah tergugat secara melawan hukum.

Sebagaimana dijelaskan Pasal 1365 mengandung konsep tanggung jawab mutlak berdasarkan kesalahan yang dapat dipaksakan dengan Liability Based Un Foult, sedangkan ass pertanggung jawaban mutlak dijelaskan ${ }^{9}$.

"Pengertian bertanggung jawab secara mutlak atau Strict Liability, yakni unsur kesalahan yang tidak perlu dibuktikan oleh pihak penggugat sebagai dasar pembayaran ganti kerugian, ketentuan ini merupakan Lex Specialis dalam gugatan terrtang perbuatan melanggar hukum pada umumnya besamya ganti rugi yang dapat dibebankan terhadap pencemar atau perusak lingkungan hidup, inidapat diHapkan sampai batas tertentu. Yang dirnaksud sampai batas tertenfu adalah jika menurut penetapan perturan perundangundangan yang berlaku, ditentukan keharusan asuransi bagi usha dan atau kegiatan yang bersangkutan atau telah tersedia dana lingkungan hidup.

\section{B. Pertanggungjawaban Secara Hukum Pidana}

Seiring dengan semakin besar peranan korporasi dalam berbagai bidang, khusunya ekonorni dan adanya kecenderungan korporasi melakukan kejahatan dalam mencapai tujuannya, maka telah terjadi

\footnotetext{
${ }^{8}$ Mas. Ahmad Santosa, Esensi Penerapan Asas Tanggung Jawab Mutal (Strict Liability) dalam Kontes Penegakan Hukum Lingkungan Indonesia, IPEL, Jakarta, 1994, hal. 27

9 Sudarto, Hukum Pidana I, 1987, hal. 89 .
} 
pergeseran pandangan bahwa korporasi juga merupakan subjek hukum pidana disamping manusia alamiah.

Sehubungan dengan konsep pelaku fungsional pertanggung jawaban dalam hukum pidana perlu dikemukakan antara lain:

Penentuan kapan suatu korporasi dinyatakan sebagai pelaku atau telah melakukan tindak pidana dan kapan suatu tindak pidana telah dilakukan atas nama suatu korporasi merupakan hal yang harus dirumuskan secara tegas. Namun untuk adanya kesalahan harus ada pencelaan etis, betapapun kecilnya, setidaknya pelaku dapat dicela karena tidk menghormati tatanan dalam masyarakat, tidak senantiasa orang yang melakukan perbutan atau orang yang tidak menghormatitat ataupun kepatutan dalam masyarakat atau melakukan Berbuatan yang dapat dikatakan tindak susila dapat dikatakanbersalah, dalam arti dapat dicela rnenurut hukum. ${ }^{31}$

Asas kesalahan (Geen Struf Zondce Schuld) merupakan asas yang fundamental dalam pemidanaan, meskipun orang telah melakukan tindak pidana, tidak selalu dipidana. Orang yang melakukan tindak pidana akan dijatuhi pidana apabila orang itu mempunyai kesalahan atau dapat dipertanggung jawabkan dalam hukum pidana. Dalam hal ini unsur kesalahan yang terdiri dari:

1. Adanya kemampuan bertanggung jawab pada sipembuat

2. hubungan batin antara si pembuat dengan perbuatannya berupa kesengajaan

3. tidak adanya alasan yang menghapuskan kesalahan atau yang tidak alasan. ${ }^{32}$

Khusus masalah kesalahan korporasi atau pertanggung jawaban pidana akan dibahas tiga (3) unsur kesalahan:

1. Masalah Kemampuan Bertanggung Jawab

Kemampuan bertanggung jawab merupakan salah satu unsur pertanggung jawaban pidana, tidaklah mungkin seorang dapat dipertanggung jawabkan apabila ia tidak mampu bertanggung jawab,

\footnotetext{
31 Sudarto, Ibid. hal. 91.
}

32 Sudarto, Ibid. 
kemampuan bertanggung jawab dapat diartikan sebagai suatu keadaan psikis sedemikian yang membenarkan adanya penerapan sesuatu upaya pemidanaan, baik dilihat dari sudut unum maupun dari orangnya, selanjutnya bahwa seseorang mampu bertanggung iawab jika jiwanya sehat yakni apabila:

a. la mampu untuk mengetahui atau menyadari bahwaperbuatannya bertentangan dengan hukum.

b. la dapat menentukan kehendaknya sesuai dengan kesadaran tersebut.

Kemampuan bertanggung jawab dalam keadaan normalitas psikis dan kematangan (kecerdasan) yang membawa 3 (tiga) kemampuan yakni $^{10}$ :

a. Mampu untuk mengerti nilai dari akibat-akibat perbuatannya sendiri.

b. Mampu untuk menyadari bahwa perbuatannya itu menurut pandangan masyarakat tidak diperbolehkan.

c. Mampu untuk menentukan kehendaknya atras perbuatanperbuatannya itu.

Menurut $^{11}$ Wolter, mampu bertanggung jawab adalah mampu untuk menginsyafi sifat melawan perbuatan hukumnya dan sesuai dengan keinsyafan itu mampu untuk menentukan kehendaknya".

Berdasarkan hal tersebut dapat dikemukakan bahwa kemampuan bertanggung jawab seseorang ditentukan oleh faktor akal, dengan akal seseorang mampu membedakan perbuatan yang baik dengan yang buruk, perbuatan yang diperbolehkan dengan yang dilarang oleh hukum. Dengan akal seseorang dapat berbuat sesuai dengan kesadaran terhadap perbuatannya, kemampuan bertanggung jawab korporasi sebagai subjek tindak pidana, menurut ${ }^{12}$ "kepelakuan fungsional (Functioneel Dudoz

10 Roeslan Saleh, Perbuatan Pidana dan Pertanggung jawaban Pidana, Dua Pengertian Dasar Dalam Hukum Pidana, Jakarta, 1983, hal. 80

11 Wolter, 1987, hal. 14.

12 J.E. Sahetapy, Kejahatan Korporasi, Bandung, 1994, hal. 37-3.8 
Schar) adalah karya interpretasi kehakiman, hakim menginterpretasikan tindak pidana itu sedemikian rupa sehingga pemidanaan memenuhi persyaratan dari masyarakat".

Sedangkan untuk meyakini adanya interpretasi fungsional dari hakim harus melalui 3 tahap yaitu ${ }^{13}$ :

1. Kepentingan yang manakah yang ingin dilindungi oleh pembentuk Undang-Undang.

2. Pribadi yang manakah dalam kasus pemidanaan ini yang dapat menjalankan atau melakukan tindak pidana.

3. Diajukan pertanyaan, apakah ada cukup pembuktian secara sahih (wettig bewijs), ternyata tidak memberikan hasil-hasil yang memuaskan.

Apabila ia menerima konsep functioneel dader schap, maka kemampuan bertanggung jawab masih berlaku dalam mempertanggung jawabkan korporasi dalam hukum pidana, sebab keberadaan korporasi tidaklah dibentuk tanpa suatu tujuan dan dalam pencapaian tujuan korporasi tersebut selalu diwujudkan melalui perbuatan manusia alamiah, oleh karena itu kemampuan bertanggung jawab orang-orang yang berbuat untuk dan atas nama korporasi dialihkan menjadi kemampuan bertanggung jawab korporasi sebagai subjek tindak pidana.

Apabila kita menerima konsep functioneel dader schap dalam mempertanggung jawabkan korporasi, kemampuan bertanggung jawaban tidak diperlukan lagi.

2. Masalah Kesengajaan dan Kealpaan Korporasi

Unsur kedua dari pertanggung jawaban atau kesalahan dalam arti yang seluas-luasnya adalah hubungan batin antara pembuat dengan perbuatannya, jadi dapat dikatakan bahwa ${ }^{14}$, sengaja berarti menghendaki dan mengetahui apa yang dilakukan, orang melakukan perbuatan dengan

13 Saleh, Op.Cit, 100-1

14 Saleh, Op.cit: 100-1 
sengaja menghendaki perbuatan itu dan ia mengetahui atau menyadari tentang apa yang dilakukan itu.

Bahwa kesalahan yang berbentuk kesengajaan dan kealpaan itu hanyalah soal gradasi saja karena15: "Kesengajaan adalah kesediaan yang disadari untuk memperkosa suatu objek yang dilindungi oleh hukum, sedangkan kealpaan adalah kekurangan pengertian terhadap obiek tersebut dengan tidak disadari".

Di dalam banyak rumusan tindak pidana ditemukan kesengajaan dan kealpaan mengingat bahwa kesengajaan dan kealpaan itu adalah unsur-unsur kesalahan dan bukanlah unsur-unsur tindak pidana, sebaiknya agar keduanya itu.

Setelah dikemukakan pemahaman pengertian kesengajaan dan kealpaan secara singkat, maka selanjutnya persoalan pertanggung jawaban pidana korporasi apabila suatu badan hukum (korporasi) dituntut, badan hukum yang tidak mempunyai jiwa manusia dapat memenuhi unsur psikis yaitu kesengajaan dan kealpaan, namun dapat dijelaskan bahwa ${ }^{16}$ kesengajaan itu terdapat dalam politik perusahaan atau berada dalam keadaan nyata dari suatu perusahaan tertentu.

3. Masalah alasan pemaaf korporasi

Alasan pemaaf amerupakan salah satu alasan penghapus pidana (Strafuitsluitings Grand), di dalam ilmu pengetahuan pidana alasan penghapus pidana dibedakan menjadi alasan pembenar, pembedaan tersebut sesuai dengan aperkembangan hukum pidana yang membedakan dapat dipidananya perbuatan dengan dapat dipidananya orang yang melakukan perbuatan.

${ }^{15}$ Saleh, Op.cit: $100-3$

${ }^{16}$ Hamzah Hatrik, Pertanggung Jawaban Korporasi Dalam Hukum Pidana Indonesia, Jakarta, 1996, hal 194. 
Alasan pembenar merupakan alasan yang meghapuskan sifat melawan hukumnya perbuatan, alasan pembenar yang terdapat dalam KUHP adalah pembelaan terpaksa (Pasal 49 ayat 1), melaksanakan ketentuan Undang-Undang (Pasal 50) dan melaksanakan perintah jabatan yang sah (Pasal 51 ayat 1), sedangkan alasan pemaaf merupakan alasan yang menghapuskan kesalahan pelakunya, yaitu tak mampu bertanggung jawab (Pasal $44 \mathrm{KUHP}$ ), pembelaan terpaksa yang melampaui batas (Pasal 49 ayat 2 KUHP) dan dengan itikad baik melaksanakan perintah jabatan yang tidak sah (Pasal 51 ayat 2 KUHP).

Selain hal tersebut, khususnya mengenai daya paksa (overmacht) yang diatur dalam Pasal 48 KUHP masih terdapat perbedaan pendapat ada yang mengatrakan sebagai alasan pemaaf bahkan ada yang mengatakan sebagai alasan pembenar dan dapat pula sebagai alasan pemaaf. Menurut ${ }^{17}$ "Overmacht yang dimaksud dalam Pasal 48 KUHP itu merupakan overmacht yang relatif, yang dapat dibedakan menjadi daya paksa dalam arti sempit (paksaan psikis) yang disebabkan oleh manusia dan keadaan darurat yang disebabkan oleh suatu keadaan alam.

Berhubung dengan korporasi sebagai subjek tindak pidana yang dapat dipertanggung jawabkan dalam hukum pidana, apakah alasan penghapus pidana khususnya alasan-alasan pemaaf berlaku terhadap korporasi sebagai konsekuensinya diterimanya asas kesalahan pada korporasi maka seperti halnya manusia alamiah, korporasi juga harus dapat menunjukkan dasar adanya alasan yang menghapus kesalahan hanya saja, alasan pemaaf sebagaimana yang diatur dalam pasal 44 KUHP, tidak dapat dihukum karena perbuatannya tidak dapat dipertanggung jawabkan karena. ${ }^{18}$ :

17 R. Susilo, Kitab Undang-Undang Hukum Pidana (KUHP, Serta Komentar Lengkap Pasal Demi Pasal), Politea, Bogor, 1986, hal. 60.

${ }^{18}$ Hamzah Hatrik, Op.Cit: hal. 103. 
1. Kurang \$empurna akalnya, yang dimaksud dengan perkataan akal ialah kekuatan pikiran, daya pikiran, orang semacam ini sebenarnya tidak sakit akan tetapi karena cacatnya mulai lahir, sehingga pikirannya tetap eebagai kanak-kanak.

2. Sakit berobah akalnya yang dapat masuk dalam pengertian ini misalnya:
a. Sakit gila
b. Manie
c. Hysterie
d. Epilepsi
e. dan bermacam-macam penyakit lainnya.

Persoalan alasan pemaaf korporasi ini masih diwamai perbedaan pendapat, tentang hal ini bahwa sesuai dengan sifat kemandirian alsanalasan peniadaan pidana, harus dicari pada korporasi itu sendiri. Dalam hal ini ditegaskan bahwa19 "Alasan-alasan penghapus pidana tentu saja juga berlaku untuk tindak pidana korporasi, hal ini tidak hanya terbatas pada AVAS (Afezigheid Van Alle Schuldl) saja, melainkan dapat mencakup yang lain misalnya daya paksa (Overmacht), dengan perkataan lain sebagaimana halnya Naturljik Persoon, badan hukum juga dapat menunjuk kepada dasarpeniadaan hukuman, namun tidak selalu ada tempat untuk menunjuk dasar peniadaan hukuman badan hukurn, jika semakin subjektif kriteria kepelakuan pidana, maka makin sedikit ruang untuk menerina ketiadaan semua kesalahan (afezigheid van alle schuld). Perlu juga ditegaskan bahwa.20; "Berdasarkan dasardasar peniadaan kesalahan (schulduitstuitings grondenl), sebenamya yang dapat diterima sebagai akibat kesalahan yang dapat dimaafkan, dasar-dasar peniadaan hukuman lainnya, adalah sangat bersifat pribadi (manusiawi) kalau digunakan tindakan untuk badan hukum kecuali menyangkut suatu badan hukum dengan hanya seorang direktur beberapa pemegang saham yang juga merangkap pelaksana.

\footnotetext{
${ }^{19}$ Muladi, Lembaga Pidana Bersyarat, Bandung, 1985,: hal. 137-138.

${ }^{20}$ Fuad Amsyari, Prinsip-Prinsip Masalah Pencemaran Lingkungan, Jakarta, 1986, hal. 11.
} 
Jurnal Justitia Vol. 1 No. 01 Agustus 2018

Konsekuensi diterimanya asas kesalahan pada korporasi, pemahaman hal ini dapat dikemukakan sebagai berikut:

1. Dalam rneniarai apertanggung jawaban pidana terhadap korporasi temyata alasan-alasan penghapus kesarahan (arasan pemaaf) tetap berlaku terhadap korporasi dengan mendasarkan kepada ketiadaan semua kesalahan.

2. Alasan-arasan pemaaf yang rain seperti daya paksa (overmacht) tidak selalu bisa diambilkan dari alasan pemaaf yang bertindak untuk dan atau atas nama korporasi.

3. Alasan pemaaf yang berupa ketidak mampuan bertanggung jawab yang diatur dalam pasar $44 \mathrm{KUHP}$ dan pembelaan terpaksa yang melarnpaui batas sebagaimana diatur dalam pasar 49 ayat 2 KUHP tidak bisa diambir arih menjadi arasan pemaaaf korporasi, karena kedua jenis alsan pemaaf ini mensyaratkan keadaan jiwa tertentu, yang mufiak hanya dapat tegadi pada diri manusia.

\section{PENUTUP}

\section{Kesimpulan}

Berdasarkan hasil penelitian dan pembahasan diperoleh kesimpulan sebagai berikut:

1. Pertanggung jawaban korporasi terhadap tindak pidana pencemaran dan atau perusakan lingkungan hidup yang menimbulkan kerugian terhadap orang lain atau lingkungan hidup, menurut peraturan mewajibkan pertanggung jawaban usaha/kegiatan untuk membayar ganti rugi meliputi aspek preventif dan aspek refresif.

2. Indikator agar pimpinan korporasi/usaha dapat diminta pertanggung jawaban hukum atas tindak pidana pencemaran dan perusakan lingkungan hidup, adalah pimpinan perusahaan yang tercantum dalam struktur perusahaan/korporasi, memberikan perintah kepada karyawan atau staf untuk melakukan pekerjaan yang berakibat 
timbulnya pencemaran atau kerusakan lingkungan hidup, serta pekerjaan tersebut bagian dari program kerja perusahaan.

3. Bentuk pertanggung jawaban yang dapat dibebankan kepada korporasi dalam hal terjadi pencemaran dan atau perusakan lingkungan hidup adalah pembayaran ganti rugi sebagai bentuk pertanggung jawaban dalam sidang perdata, hukum pidana, dan pencabutan izin usaha.

\section{Dafar Pustaka}

\section{A. Buku}

Amsyari Fuad, Prinsip-Prinsip Masalah Pencemaran Lingkungan, Jakarta, 1986.

H. Setiyono, Kejahatan Korporasi, Jakarta, 1997.

Hatrik Hamzah, Azas Pertanggung Jawaban Korporasi Dalam Hukum Pidana Indonesia, Jakarta, 1996.

Hardjasoemantri Koesnadi, Hukum Tata Lingkungan, Edisi ketujuh, Gadjah Mada University Press Yogyakarta, 2001.

Kantaatmadja Komar, Ganti Rugi Internasional Pencemaran Minyak Laut, Jakarta, 1981.

M. Daud Silalahi, Hukum Lingkungan Dalam Sistem Penegakan Hukum Lingkungan, Bandung, 2001.

Muhammad Abdul Kadir, Hukum dan Penelitian Hukum, Citra Aditya, Bandung, 2004.

M. Hamdan, Tindak Pidana Pencemaran Lingkungan Hidup, Mandar Maju, Bandung, 2000.

Mas Ahmad Santosa Dkk. Penerapan Azas Tanggung Jawab Mutlak di bidang Lingkungan Hidpup, IPEL, Jakarta, 1997.

Mutal (Strick Leability) dalam kontes Penegakan Hukum Lingkungan Indonesia, Jakarta, 1984. 
Muladi, Fungsionaliasai Hukum Pidana Dalam Kejahatan Yang dilakukan oleh Korporasi, Jakarta, 1989. ,Lembaga Pidana Bersyarat, Bandung, 1985 , Pertanggung Jawaban Korporasi Dalam Hukum Pidana, Bandung, 1991.

N.H.T. Siahaan, Hukum Lingkungan dan Ekologi Pembangunan, Jakarta, 2004. 1987. ,Ekologi Pembangunan dan Hukum Tata Lingkungan, Jakarta,

Propenas, 2000-2004, Sinar Grafika, Jakarta, 2003.

Salim Emil, Lingkungan Hidup dan Pembangunan, Jakarta, 1997.

Soemarwoto Otto, Permasalahan Lingkungan Hidup, Jakarta, 1977.

Subekti, Pokok-Pokok Hukum Perdata, Jambatan Mas, Jakarta, 1975,

Soesilo R., Kitab Undang-Undang Hukum Pidana, Politeia, Bogor, 1986.

Kitab Undang-Undang Hukum Pidana (KUHP, serta Komentar Lengkap Pasal Demi Pasal), Politea, Bogor, 1998.

R. Subekti, Kitab Undang-Undang Hukum Perdata, Pradnya Paramita, Jakarta, 1989. , Pokok-Pokok Hukum Perdata. Jakarta, 1975.

Saleh, Roeslan, Perbuatan Pidana dan Pertanggung Jawaban Pidana, Dua Pengertian Dasar Dalam Hukum Pidana, Jakarta, 1983.

Sahetapy, J.E, Kejahatan Korporasi, Bandung, 1984.

Salim, H.S., Dasar-Dasar Hukum Kehutanan, Sinar Grafika, Jakarta, 2003.

Siti Sundari Rangkuti, Pembinaan Hukum Lingkungan Administratif Hukum Lingkungan Keperdataan dan Hukumm Lingkungan Kepidanaan, UNAIR, Surabaya, 1984.

S.T. Munadjat Danusaputro, Hukum Lingkungan Buku I, Jakarta, 1985.

Sudarto, Hukum Pidana I, Jakarta, 1987.

Wijaya, G.Rai, Hukum Perusahaan Perseroan Tebatas, Kesaint Blanc, 2000. 
Jurnal Justitia Vol. 1 No. 01 Agustus 2018

\section{B. Perundang - Undangan}

Undang-Undang No. 23 tahun 1997 tentang Lingkungan Hidup. UndangUndang No. 4 tahun 2001 tentang Pengendali.an Kerusakan/ Pencemaran Lingkungan Hidup.

Undang-Undang No. 41 tahun 1999 tentang Kehutanan Undang-

Undang No. 8 tahun 1998 tentang Perlindungan Konsumen Undang-

Undang No. 18 tahun 2004 tentang Perkebunan

Undang-Undang No. 23 tahun 1997 tentang Pengelolaan Lingkungan Hidup. 